\title{
1. Introduction: New Challenges to Economic Diplomacy
}

Economists and diplomats are different specimen. For long they could neglect each other's existence. Typically economic and commercial policies were labelled 'low politics' by statesmen and diplomats. At first sight the tough dynamic world of commerce and the subtle glamour of diplomacy do not have much in common, but as any newspaper reader knows, international economic relationships are an important factor in the diplomatic sphere of influence and vice versa. 'No matter who reigns, the merchant reigns.' 'Trade follows the flag.' This book takes a closer look at international economics and politics. Economic diplomacy (of which commercial policy is an important element) is at the interface between these subject fields as its aim is to influence decisions about cross-border economic activities (export, import, investment, lending, aid and migration) pursued by governments and nonstate actors. A closer study of the interrelationships between, on the one hand, diplomacy and politics and, on the other hand, trade, investment and capital is warranted from a broader theoretical perspective. Mainstream neoclassical economic theory typically tends to pay little if any attention to public policy in the context of bilateral economic relationships. This is an undesirable situation and one can only agree with Bhagwati (1991, p. xvi) when he complains 'How can we possibly explain what happens unless we bring in the political equations into our modelling at the same time?' The lack of attention may be due to the fact that the economic recipe is to specialize according to comparative advantage and to avoid subsidies and other distorting government policies that reduce welfare. Indeed, most textbooks in international economics do not pay attention to the inherent political character of international economic exchange. A case in point is Ricardo's Principles of Political Economy and Taxation ([1817] 1962, para. 7.1) which develops the theory of comparative advantage as an explanation for the 'natural trade' that leads Portugal to export wine and England to export cloth:

Under a system of perfectly free commerce, each country naturally devotes its capital and labour to such employments as are most beneficial to each. This pursuit of individual advantage is admirably connected with the universal good of the whole. By stimulating industry, by regarding ingenuity, and by using most efficaciously the peculiar powers bestowed by nature, it distributes labour most 
effectively and most economically: while, by increasing the general mass of productions, it diffuses general benefit, and binds together by one common tie of interest and intercourse, the universal society of nations throughout the civilized world.

The issue, however, that is relevant for our discussion is that the trade in wine and cloth between Portugal and England had not been the outcome of free trade at all. It was the result of economic diplomacy and arranged in the context of the Methuen Treaty, a military and commercial treaty between Portugal and England signed in 1703 as part of the War of the Spanish Succession. ${ }^{1}$ In addition, the treaty helped to establish trading relations between England and Portugal. The trade agreement that formed part of the treaty set a zero tariff on English woollen cloth and reduced the duties on Portuguese wines by a third giving Portugal a clear competitive edge vis-à-vis France. ${ }^{2}$ The upshot clearly is that comparative advantage is only one side of the coin and that economic diplomacy and economic security can be drivers of trading patterns. Indeed, as pointed out by Adam Smith ([1776] 1976, p. 179), the treaty diverted potential imports from France towards Portugal:

By the famous treaty of commerce with Portugal the consumer is prevented by high duties from purchasing of a neighbouring country, a commodity which our own climate does not produce, but is obliged to purchase it of a distant country, though it is acknowledged, that the commodity of the distant country is of a worse quality than that of the near one.

According to O'Brien (1976, 544-48) the trade diversion element became a standard objection against commercial treaties and was included in the major works of Classical economists (including Hume, McCullogh and Say). ${ }^{3}$ Actually, this negative verdict of commercial treaties may very well be one of the explanations why modern trade economists have tended to shy away from the interrelated issues of commercial policy and economic diplomacy.

\section{A BRIEF HISTORY OF ECONOMIC DIPLOMACY}

Since the start of the third millennium the interrelated issues of economic diplomacy and economic security have risen to the top of the international policy agenda. A mix of political and economic drivers can be discerned behind this rise: the integration of formerly communist countries into the world economy, the 'new' scarcity (reflected by unprecedented increases in the prices of oil, raw materials and other essential goods and products), global warming and the occurrence of new forms of conflict such as transnational terrorism. Characteristic of the present era is the intensity of multidimensional relations between nations and people around the globe. This 
creates tremendous commercial opportunities in newly emerging markets and this economic potential is one reason for the increased interest amongst scientists and policy makers in economic diplomacy and commercial policy.

Figure 1.1 illustrates the increasing intensity of international interaction for the field of economic diplomacy in the second half of the twentieth century, charting two visible aspects in the arena of international politics: state visits and economic sanctions (such as boycotts and embargoes). By the year 2000 the deployment of economic sanctions that aimed to achieve foreign policy goals was four times as high as the 1950s level; in the same period typical foreign policy activities related to commercial policy increased even stronger as shown by the eightfold increase in the number of state visits by Heads of State of the US, Germany and France.

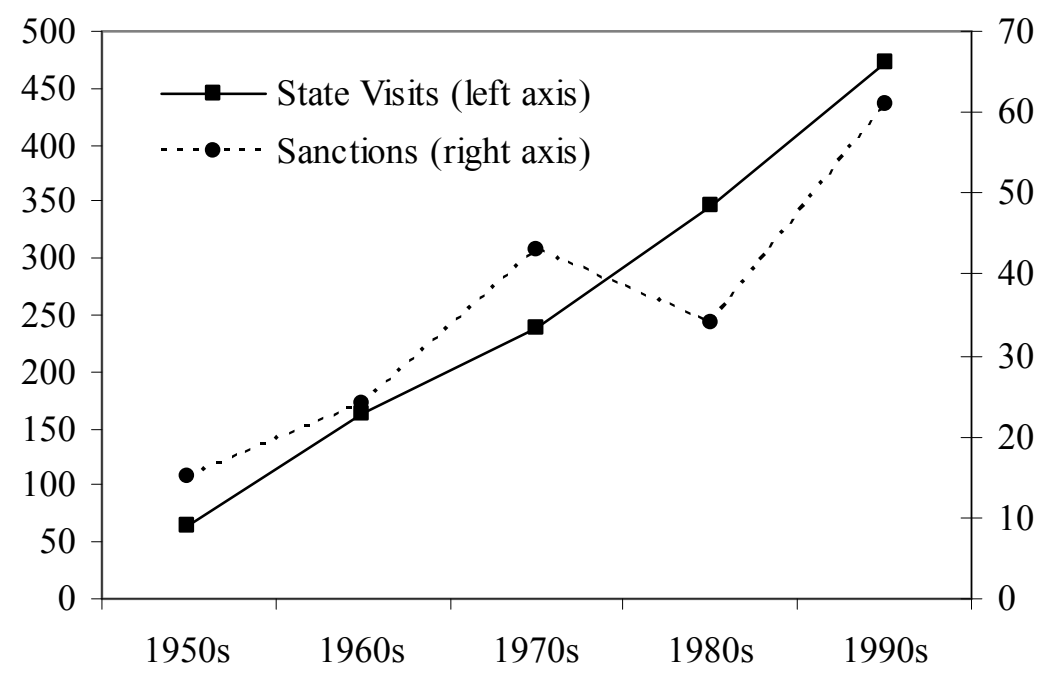

Sources:

Nitsch (2007, p. 1800, Table 1); all visits by Heads of State from France, Germany and the United States.

Hufbauer et al. (2008), database on CD-ROM.

Figure 1.1 Trends in economic diplomacy 1950-1999

One of the most important aspects of the present phase of the globalization process is the fact that the formerly communist states have become more market-oriented economies and participate to a much larger extent in the world economic system than previously. Although their performance is already impressive, much is still in the pipeline and by 2025 the OECD's latest world model (Hervé et al. 2007) predicts that the old group 
of trading nations (Europe and North America) will have lost their majority position in terms of trade shares; see Table 1.1.

Table 1.1 Trade shares by major countries and country groupings for the years 1995 and 2025 (in \%)

\begin{tabular}{lcc}
\hline & 1995 & 2025 \\
\hline United States & 16 & 11 \\
Euro Area & 29 & 18 \\
Non-euro Europe & 11 & 5 \\
Japan & 7 & 4 \\
China & 2 & 17 \\
Rest of Asia & 14 & 15 \\
Rest of the World & 21 & 30 \\
\hline
\end{tabular}

Source: Hervé et al. (2007)

In particular the trade share of Asia would increase from $23 \%$ in 1995 to $36 \%$ in 2025 whereas the share of the European Union over the same period would decrease from $40 \%$ to $23 \%$. This development is relevant for two reasons. First, many firms in the newly emerging economies are state-owned and trade and investment relations often require government to government contacts. Second, the combined share of the United States and the European Union will reduce to about one third of world trade in 2025 . This will clearly have consequences, because an increase in the number of countries that participate in international trade negotiations will complicate and slow international consensus building. ${ }^{4}$ Moreover, the emergence of new economies with very different institutions and cultural background will influence global norms and values and this will undoubtedly have an impact on the rules of international trade and investment. In particular the historical, cultural and institutional background of China and India may in the long run exert an influence on the ways the world defines and settles international conflicts.

The emergence of these new players offers a challenge for economic diplomacy and to a large extent explains why interest of economic scholars in commercial policy has increased following seminal work by Strange (1998) on new modes of diplomacy. One relevant result of academic research has been a strengthening of the empirical base regarding the mutual impact of trade and politics, which we consider in the next section. 


\section{EMPIRICAL EVIDENCE}

Econometric investigations since the early 1990s consistently show that economic diplomacy is empirically relevant. The empirical basis is illustrated in Table 1.2 (the studies are discussed in Chapter 2). The table summarizes empirical studies that deal with both the conflict-trade relationship (that is the questions of how conflicts hinder international trade or how the reduction of conflict increases trade) and the trade-conflict relationship (that is how does international trade influence conflict and co-operation between nations). The table lists 18 studies, starting with Polachek's seminal 1980 article on the impact of trade on international conflict regarding 30 countries and the period 1958-67 and ending with a number of studies that followed up on Rose's (2007) investigation of the influence of the embassies and consulates of 20 exporting countries regarding 220 export destinations. The studies together provide a rich sample that covers the post-Second World War period and includes the 1990s (this is relevant since this decade is often seen as the start of a new phase of the globalization process). ${ }^{5}$ Indeed, it is important that the relationships have been established both prior to 1990 and after 1990 (when the Iron Curtain fell and détente set in).

\section{Box 1.1 Gravity in a nutshell}

The gravity model (which will be discussed in more detail in Chapter 5) is an applied empirical trade model that describes bilateral trade flows. The key drivers in this model are economic mass and distance. Just as in the Newtonian gravity model this trade model assumes that interaction is weaker if distance is larger and stronger when masses are larger. Thus a large country that has substantial production and population will ceteris paribus trade more than a small country. Likewise countries that are closer to each other trade more. Often the model also includes a great number of trade resistance factors (such as import tariffs) and trade enhancement factors (such as a common language) that are relevant at the bilateral level.

Typically the empirical investigations use a gravity model approach in which distance and economic or political mass (proxied by GDP, population and so on) are the drivers for the dependent variable which is listed in the second column of Table 1.2. The third column reports the main explanatory variable of interest. The fourth and fifth column report the number of countries $N$ and the period that has been investigated. 
Table 1.2 Summary of empirical studies on the relationship between trade, conflict and instruments of international politics and commercial policy

\begin{tabular}{|c|c|c|c|c|c|}
\hline Study & $\begin{array}{l}\text { Dependent } \\
\text { variable }\end{array}$ & $\begin{array}{l}\text { Exogenous } \\
\text { variable }^{\mathrm{a}}\end{array}$ & $N^{b}$ & Period & Elasticity \\
\hline Polachek 1980 & Conflict & $\begin{array}{l}\text { Export, } \\
\text { Import }\end{array}$ & 30 & $1958-67$ & $0.15 / 0.31$ \\
\hline $\begin{array}{l}\text { Gasiorowski } \\
1986\end{array}$ & Conflict & Trade & 44 & $1960-77$ & 0.33 \\
\hline Pollins 1989b & Trade & Conflict & 25 & $1960-75$ & $0.04 / 0.37$ \\
\hline Summary 1989 & US trade & Conflict & 66 & $1978-82$ & $0.2 / 0.3$ \\
\hline Bergeijk 1989b & Trade & Co-operation & 25 & $1966-70$ & $0.2 / 0.49$ \\
\hline $\begin{array}{l}\text { Polachek et al. } \\
1992\end{array}$ & Conflict & Trade & 105 & $1948-78$ & $0.12 / 0.50$ \\
\hline Bergeijk 1994a & Trade & Co-operation & 40 & 1985-86 & $0.23 / 0.60$ \\
\hline $\begin{array}{l}\text { Mousseau et al. } \\
2003\end{array}$ & $\begin{array}{l}\text { Military } \\
\text { conflict }\end{array}$ & Trade & n.a. & $\begin{array}{c}1885- \\
1992\end{array}$ & $-0.3 /-0.4$ \\
\hline $\begin{array}{l}\text { Nitsch et al. } \\
2004\end{array}$ & Trade & Terrorism & 200 & $1960-93$ & $0.01 / 0.10$ \\
\hline Li et al. 2004 & Terrorism & Trac & 112 & 1975-97 & 0.001 \\
\hline $\begin{array}{l}\text { Blomberg et al. } \\
2006\end{array}$ & Trade & Terrorism & 177 & 1968-99 & $0.04 / 0.05$ \\
\hline $\begin{array}{l}\text { Freytag et al. } \\
2006\end{array}$ & Terrorism & Trade & 96 & $2000-02$ & u-shaped \\
\hline $\begin{array}{l}\text { Fratianni et al. } \\
2006 \mathrm{a}\end{array}$ & Trade & Terrorism & n.a. & 1980-99 & $0.01 / 0.10$ \\
\hline $\begin{array}{l}\text { Lederman et al. } \\
2006\end{array}$ & Export & $\begin{array}{l}\text { Export } \\
\text { Promotion }\end{array}$ & 104 & 2002-04 & $0.07 / 0.11$ \\
\hline Rose 2007 & Trade & Embassies & $20^{\mathrm{c}}$ & 2002 & $0.08 / 0.11$ \\
\hline $\begin{array}{l}\text { Gil-Pareja et al. } \\
2007\end{array}$ & Tourism & Embassies & $7^{\mathrm{d}}$ & & $0.15 / 0.30$ \\
\hline $\begin{array}{l}\text { Maurel et al. } \\
2007\end{array}$ & Trade & Embassies & 56 & $\begin{array}{l}1997- \\
2005\end{array}$ & $0.07 / 0.17^{\mathrm{e}}$ \\
\hline $\begin{array}{l}\text { Yakop et al. } \\
2007\end{array}$ & Trade & Embassies & 63 & 2006 & $0.06 / 0.13$ \\
\hline Nitsch 2007 & Trade & State visits & $3^{c}$ & 1948-2003 & $0.08 / 0.13$ \\
\hline
\end{tabular}

\section{Notes:}
a. This column reports only the result for the most important explanatory variable in the multiple regressions.
b. Number of countries included in the study.
c. Number of exporting countries; number of export markets amount to 220 .
d. G7 vis-à-vis 156 countries.
e Estimates according to the specification by Rose (2007). 
Finally, the table reports in the penultimate column the (range for the) relevant elasticity between on the one hand, the political (or diplomatic) variables and on the other hand, the trade variables (import, export). Generally speaking, this elasticity is significantly different from zero and in the range of 0.001 to 0.5 with an average of 0.17 (the standard deviation of the reported co-efficient in Table 1.2 is 0.16 ).

The econometric studies summarized in Table 1.2 are conclusive regarding the three key theoretical propositions that have been developed in the conflict-trade and trade-conflict literatures.

- An increase in conflict (for example, negative military and diplomatic exchange, international terrorism) significantly reduces bilateral trade.

- An increase in co-operative behaviour (for example, positive and constructive diplomatic exchanges and agreements) increases bilateral trade.

- An increase in international economic exchange (export, import, foreign investment, aid and so on) reduces conflict (wars, transnational terrorism and so on ).

The rise of economic diplomacy and international security on the policy agenda since the turn of the century is also reflected in the increase in the number of studies that have become available. A number of researchers (Nitsch et al. 2004, Li et al. 2004, Blomberg et al. 2006 and Fratianni et al. 2006a) have recently dealt with the new issues of the impact of terrorism on trade and vice versa. Transnational terrorism is a substitute for traditional violence between nations and thus offers an additional challenge to international security. It reduces trust between and within trading nations and their populations and has a measurable negative impact on trade. The bright side is that the empirical evidence suggests that both increasing economic ties and economic development tend to reduce the very basis from which terrorism emerges.

A second, relatively recent, line of research emerges in Table 1.2, namely the empirical research into the impact of export promotion agencies, state visits, embassies and consulates on trade in goods and services. This strand of the literature includes studies by Lederman et al. (2006), Nitsch (2007), Rose (2007), Gil-Pareja et al. (2007), Maurel and Afman (2007) and Yakop et al. (2007). These studies consistently find significant and empirically relevant indications for trade creation by means of economic diplomacy. Maurel and Afman (2007), for example, estimate that the opening of an embassy is equivalent to an ad valorem tariff reduction of $2 \%$ to $8 \%$.

Obviously, the issue of causality is not completely settled given the different research approaches and theories so there is - as yet - no definite 
scientific proof whether international trade determines political and diplomatic relationships between countries or vice versa. ${ }^{6}$ The correlation, however, is robust so it would seem to be beyond scientific doubt that the interrelationship between international politics and economics is a topic worth of further investigation.

The empirical evidence on the relationship between international politics and economics is further strengthened by econometric investigations into the determinants of success and failure of economic sanctions. This line of research has been stimulated by the study Economic Sanctions Reconsidered (Hufbauer and Schott 1985) which was first published in 1985 by the Peterson Institute for International Economics. Table 1.3 summarizes empirical research into the determinants of failure and success related to the 1985 and 1990 data set as well as the econometric estimates that are included in or relate to the third edition of this study (Hufbauer et al. 2008). The empirical analyses that were carried out by Hufbauer et al. have on different accounts been criticised. Indeed, also their latest econometrics have some serious flaws. We will re-analyse their data sets in Chapter 6.

Table 1.3 Summary statistics for recent empirical investigations into the effectiveness of economic sanctions

\begin{tabular}{|c|c|c|c|c|}
\hline Study & $N$ & Period & $\begin{array}{c}\text { Trade } \\
\text { parameter }\end{array}$ & Estimate \\
\hline \multicolumn{5}{|c|}{ Investigations based on the 1985 data set } \\
\hline Hufbauer et al. (1985) & 108 & $1914-83$ & ATL & 0.031 \\
\hline Bergeijk (1989a) & 80 & $1946-83$ & PTL & $0.21^{\$}$ \\
\hline Lam (1990) & 98 & $1914-83$ & ATL & 0.008 \\
\hline \multicolumn{5}{|c|}{ Investigations based on the 1995 data set } \\
\hline Dehejia and Wood (1992) & 115 & $1914-89$ & ATL & 0.002 \\
\hline \multirow[t]{2}{*}{ Bergeijk (1994a) } & 103 & $1946-89$ & ATL & $0.036^{\#}$ \\
\hline & 92 & $1946-89$ & PTL & $0.15^{\$}$ \\
\hline \multirow[t]{2}{*}{ Bonetti (1998) } & 104 & $1946-89$ & ATL & $0.10^{\$}$ \\
\hline & & & $\mathrm{ATL}^{2}$ & $-0.002^{\$}$ \\
\hline \multicolumn{5}{|c|}{ Investigations based on the 2008 data set } \\
\hline Hufbauer et al. (2008) & 174 & 1914-99 & ATL & 0.01 \\
\hline Bergeijk and Fenthur (2008) & 150 & 1946-99 & PTL & $0.06^{\$}$ \\
\hline
\end{tabular}

Notes: $\quad$ significant at $99 \%$, \# significant at $95 \%$,

ATL is average trade linkage

PTL is proportional trade linkage 
The economic researchers that have investigated the Hufbauer et al. data sets have used different econometric methods and have applied judgement both regarding the reliability of data in specific sanction cases and the need to consider different sets of explanatory variables. Sometimes variables that were not included in the Hufbauer et al. data sets have also been used; in contrast other researchers have completely relied on the Hufbauer et al. data sets. So while all studies in Table 1.3 start from the same data set and use the judgement of Hufbauer et al. on the outcome of sanctions, different research designs led to different numbers of observations $N$ for the reported studies.

The relevant mirror question (do sanctions influence bilateral trade?) has also been investigated. Deploying a gravity model Hufbauer et al. (2008, pp. 201-207) estimate trade elasticities of US sanctions with respect to US bilateral trade flows that are significant at the usual 95\% confidence level and better and are in the range of -0.39 to -0.19 . Estimates by Farmer (2000) of the costs of sanctions for the sender (that is for the country that imposes the sanctions) reveal meaningful but smaller impacts.

All in all sufficient empirical evidence is available to substantiate the claim that international trade and politics mutually exerted strong influences in the post-Second World War period. Obviously this is a backward-looking answer as it is based on real world observations which by definition relate to the past. The forward-looking question asks how trade patterns may change especially in relation to the observed increasing deployment of economic diplomacy.

It is thus relevant that it has been argued that globalisation reduces the distance between countries due to the Internet, reduced transportation costs and the ease of travelling and communication. The death of distance has been announced by amongst others Cairncross (1997) and Friedman (2005). In a truly 'global village' the difference between external trade and internal trade would seem to disappear and less, if any, need exists for the state to intervene through economic diplomacy. In the flat world of Friedman no difference could after all be discerned between internal and external trade. So a nagging empirical question emerges that needs to be answered before we can proceed with our discussion of economic diplomacy. Do border effects (continue to) exist and in particular: what has happened to the distance effect in international trade?

\section{DISTANCE IS NOT DEAD, IT IS HETROGENEOUS}

So: does distance still matter? This is a relevant question for any student of economic diplomacy. If distance does not matter or matters much less than before, then foreign trade and domestic trade become closer (and perhaps 
perfect) substitutes and it becomes difficult to see a role for the public sector. Essentially, this is an empirical question and a topic of much debate among trade economists. A counterintuitive finding of the empirical literature is that the impact of distance, despite stronger globalization, has at least remained as important as it used to be in international trade. An example is provided by the meta analysis of the existing scientific literature by Disdier and Head (2008). They report on the basis of 103 scientific econometric studies for the years 1870-2000 and a good 1500 estimated distance parameters. Their analysis shows that the distance decay effect is on average one third stronger in the more recent period 1990-2000 compared to the average finding for the years 1870-1970. This result is a general finding in the empirical trade literature. ${ }^{7}$ It implies that on average distance has become more important; indeed border effects remain substantial even within the European Monetary Union although on a downward trend (see, for example, Rae and Sollie, 2007 and Helble, 2007).

\section{Table 1.4 Impact of a one standard deviation change in intangible trade barriers (\% change)}

\begin{tabular}{lcc}
\hline Intangible Barrier & Export & $\begin{array}{c}\text { Foreign Direct Investment } \\
\text { (Stock) }\end{array}$ \\
\hline Increase in trust & $24-38^{\mathrm{a}, \mathrm{b}, \mathrm{c}}$ & $75-111^{\mathrm{a}, \mathrm{c}}$ \\
Decrease in cultural diversity & $-14-8^{\mathrm{a}, \mathrm{d}, \mathrm{e}}$ & $16-28^{\mathrm{a}, \mathrm{e}}$ \\
Increase institutional quality & $22-45^{\mathrm{d}}$ & $14-33^{\mathrm{e}}$ \\
\hline
\end{tabular}

Source: Adapted from van den Berg et al. (2008), Table 3.6, pp. 37-38.

Notes: $\quad$ a. Dekker et al. (2006)

b. den Butter and Mosch (2003)

c. Guiso et al. (2004)

d. Linders et al. (2005)

e. Lankhuizen et al. (2008)

Given the reduction of transportation costs, this finding suggests that other non-economic factors related to preferences, culture and institutions may have become more important barriers to trade over the last decade or so. ${ }^{8}$ Cultural distance has probably always been important but may have remained unnoticed under the veil of physical distance. Indeed, recent investigations have uncovered a significant impact of intangible barriers such as cultural diversity, international (dis)trust and the quality of institutions, as illustrated by Table 1.4 that summarizes the empirical literature.

Since commercial policy and economic diplomacy are especially aimed at bridging these intangible barriers it would not seem far-fetched to expect that 
such policies may play an important role in shaping the geographical trading patterns of nations. If so, we would expect to observe different developments for different countries since the effectiveness of and inputs available for economic diplomacy and commercial policy vary greatly between nations (see Riberio 2007, pp. 156-87 for an overview).

I will investigate this question econometrically using a small quasireduced form equation for the years 1995 and 2004 focussing on differences in the impact of distance both over time and between countries. In order to check for the heterogeneity of the distance parameters, I regress the distance $d$ on the bilateral export-to-GDP ratio $x$. This ratio $x$ is defined as the export from country $A$ to country $B$ divided by the exporter's Gross Domestic Product. The variable $d$ represents the distance that goods have to be transported between the exporter's home market (or production facilities) and the target foreign market. In addition I take into account the extent of the export market which is proxied by the importer's Gross Domestic Product $y$. The equation to be estimated is:

$$
x_{\mathrm{t}}=\alpha\left(1+\delta_{2004}\right) d+\beta y_{\mathrm{t}}+c+u
$$

where $x$ is the bilateral export-to-GDP ratio, $d$ is distance, $\delta_{2004}$ is a dummy variable that is 1 in 2004 (else 0), $y$ is the importer's GDP, $t=1995$ or 2004, $c$ is the constant term, $u$ is an error term and $x, d$ and $y$ have been expressed in natural logarithm. A priori one expects a negative sign for $\alpha$ (one trades less with more distant countries) and a positive sign for $\beta$ (one trades more with bigger countries). The parameter of particular interest in this investigation is $\delta_{2004}$. If $\delta_{2004}$ is positive then distance has become more important and if it is negative then distance has become less important in shaping the geographical trading pattern. The empirical investigation pertains to a group of 29 exporting countries and 44 export markets. The sample covers all continents and investigates exporting countries at all levels of development. The investigation deals with almost three quarters of world trade. The number of observations is 2474. Using Ordinary Least Squares for the sample as a whole the following equation is estimated (all estimated parameters are significant at the $95 \%$ confidence level and better and adjusted- $\left.R^{2}=0.63\right)$ :

$$
\ln (x)=-0.827\left(1+0.0169 \delta_{2004}\right) \ln (d)+0,82 \ln (y)-28.0
$$

The positive co-efficient for $\delta_{2004}$ is in line with the meta analysis of Disdier and Head (2008) since we also find that distance has become more important over time (the negative trade parameter increases). An interesting question is whether this average finding for the whole population can also be 
discerned at the level of individual countries. Therefore Table 1.5 and Figure 1.2 report econometric results regarding 29 equations that have been individually estimated for the exporting countries, and the change in trade resistance (as measured by parameter $\delta_{2004}$ ), respectively. The results of the empirical investigation are satisfactory from a statistical point of view. The estimated parameters for distance and the importer's national income are significant at the usual confidence levels of $95 \%$ and better and roughly 60 to $90 \%$ of the variance in bilateral trade to GDP ratios is explained by the estimated individual country equations.

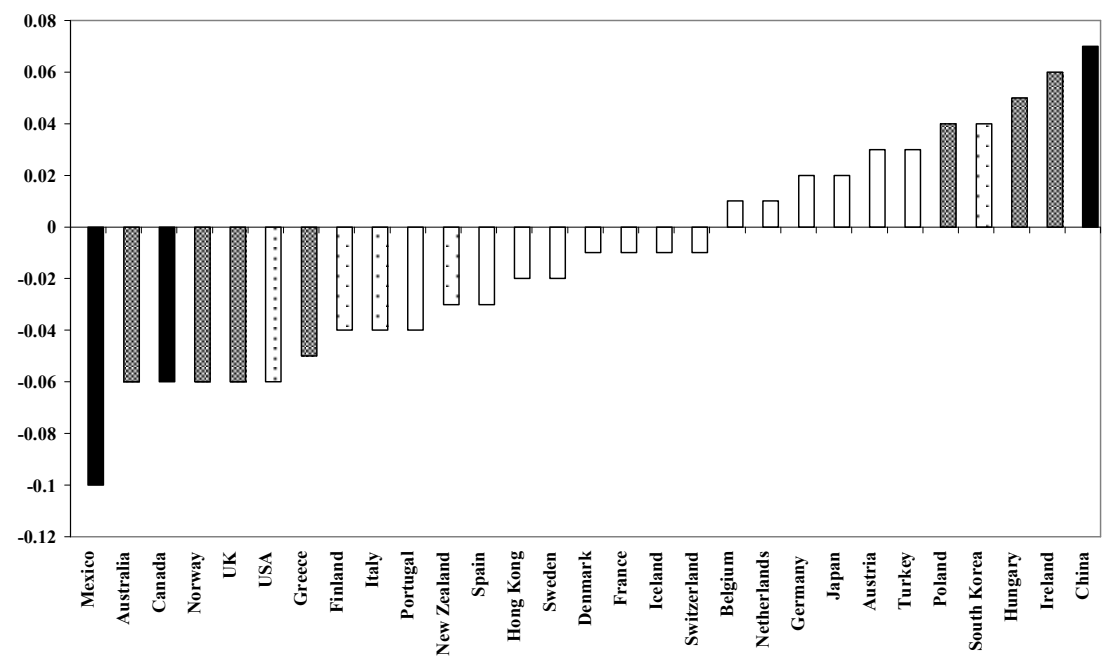

Note: Significance levels are denoted as $\square 99 \%, 095 \%, \square 90 \%$

Figure 1.2 Change in distance parameter 1995-2004

The results point out significant heterogeneity in the impact of distance on national geographical trade patterns as illustrated in Figure 1.2. ${ }^{9}$ Distance appears to have become more important for countries such as China, Hungary, Ireland, Poland and Korea; but it seems to have become a less important determinant of geographical trade patterns for the member countries of the North American Free Trade Agreement (NAFTA), Australia, Greece, Finland and Spain). Consequently, the measured reduction of the distance effect could reflect different modes of integration into the world economic system. 
Table 1.5 Empirical results of the OLS estimation of the bilateral trade to GDP ratios for individual countries 1995 and $2004(N=2994)$

\begin{tabular}{|c|c|c|c|c|c|c|}
\hline Country & Distance $(\alpha)$ & $\begin{array}{c}\text { Dummy } \\
\left(\delta_{2004}\right)\end{array}$ & $\begin{array}{c}\mathrm{GDP}_{\mathrm{j}} \\
(\beta)\end{array}$ & Constant & $\begin{array}{c}\text { adj.- } \\
R^{2} \\
\end{array}$ & F-test \\
\hline Australia & $-3.15^{\$}$ & $-0.06^{\#}$ & $1.09^{\$}$ & $-13.12^{\$}$ & 0.78 & 104 \\
\hline Austria & $-0.83^{\S}$ & 0.03 & $0.86^{\$}$ & $-29.52^{\$}$ & 0.76 & 92 \\
\hline Belgium & $-0.37^{\$}$ & 0.01 & $0.77^{\$}$ & $-26.77^{\$}$ & 0.85 & 172 \\
\hline Canada & $-0.27 *$ & $-0.06^{\$}$ & $1.02^{\$}$ & $-38.43^{\$}$ & 0.80 & 117 \\
\hline China & $-1.17^{\$}$ & $0.07^{\$}$ & $0.82^{\$}$ & $-25.03^{\$}$ & 0.73 & 80 \\
\hline Denmark & $-0.77^{\$}$ & -0.01 & $0.69^{\$}$ & $-25.12^{\$}$ & 0.77 & 95 \\
\hline Finland & $-0.68^{\$}$ & $-0.04 *$ & $0.80^{\$}$ & $-28.37^{\$}$ & 0.77 & 96 \\
\hline France & $-0.59^{\$}$ & -0.01 & $0.70^{\$}$ & $-27.01^{\$}$ & 0.79 & 155 \\
\hline Germany & $-0.66^{\$}$ & 0.02 & $0.79^{\$}$ & $-28.53^{\$}$ & 0.87 & 195 \\
\hline Greece & $-1.31^{\$}$ & $-0.05^{\#}$ & $0.70^{\$}$ & $-22.24^{\$}$ & 0.72 & 73 \\
\hline Hong Kong & $-0.88^{\$}$ & -0.02 & $1.00^{\$}$ & $-30.53^{\$}$ & 0.67 & 59 \\
\hline Hungary & $-1.23^{\$}$ & $0.05^{\#}$ & $0.89^{\$}$ & $-27.35^{\$}$ & 0.84 & 155 \\
\hline Iceland & $-1.37^{\$}$ & -0.01 & $1.05^{\$}$ & $-29.31^{\$}$ & 0.60 & 43 \\
\hline Ireland & $-0.73^{\$}$ & $0.06^{\#}$ & $0.83^{\$}$ & $-28.22^{\$}$ & 0.72 & 73 \\
\hline Italy & $-0.65^{\S}$ & $-0.04 *$ & $0.72^{\$}$ & $-26.80^{\$}$ & 0.80 & 112 \\
\hline Japan & $-1.49^{\$}$ & 0.02 & $0.82^{\$}$ & $-22.47^{\$}$ & 0.73 & 78 \\
\hline Mexico & $-1.16^{\$}$ & $-0.10^{\$}$ & $1.18^{\$}$ & $-35.00^{\$}$ & 0.71 & 70 \\
\hline Netherlands & $-0.74^{\$}$ & 0.01 & $0.68^{\$}$ & $-24.72^{\$}$ & 0.86 & 171 \\
\hline N-Zealand & $-1.51^{\$}$ & -0.03 & $1.02^{\$}$ & $-26.13^{\$}$ & 0.67 & 59 \\
\hline Norway & $-0.94^{\$}$ & $-0.06^{\#}$ & $0.82^{\$}$ & $-27.13^{\$}$ & 0.64 & 50 \\
\hline Poland & $-1.24^{\$}$ & $0.04^{\#}$ & $0.72^{\$}$ & $-22.97^{\$}$ & 0.86 & 166 \\
\hline Portugal & $-1.17^{\$}$ & -0.04 & $0.79^{\$}$ & $-24.67^{\$}$ & 0.72 & 73 \\
\hline Korea & $-1.10^{\$}$ & $0.04 *$ & $0.52^{\$}$ & $-17.23^{\$}$ & 0.67 & 57 \\
\hline Spain & $-0.86^{\$}$ & $-0.03 *$ & $0.74^{\$}$ & $-25.90^{\$}$ & 0.82 & 126 \\
\hline Sweden & $-0.71^{\$}$ & -0.02 & $0.77^{\$}$ & $-27.25^{\$}$ & 0.83 & 135 \\
\hline Switzerland & $-0.33^{\$}$ & -0.01 & $0.83^{\$}$ & $-32.09^{\$}$ & 0.81 & 124 \\
\hline Turkey & $-1.36^{\$}$ & 0.03 & $0.76^{\$}$ & $-22.80^{\$}$ & 0.73 & 78 \\
\hline UK & $-0.47^{\$}$ & $-0.06^{\#}$ & $0.63^{\$}$ & $-25.84^{\$}$ & 0.63 & 73 \\
\hline USA & -0.29 & $-0.06^{*}$ & $0.89^{\$}$ & $-35.01^{\$}$ & 0.61 & 45 \\
\hline
\end{tabular}

Notes: \$ significant at 99\%, \# significant at 95\%, * significant at $90 \%$ 
The opening up of China and the former members of the Comecon (the communist country trading system) and regional integration and trade reorientation within NAFTA affect the geographic pattern of trade and thus the measured impact of distance. Diverging country experiences can even be observed within homogeneous country groups such as the European Union. Interestingly, this European heterogeneity cannot be explained by developments on the European continent such as the end of the Cold War in 1990 (Bergeijk and Oldersma, 1990) or the creation of the European Monetary Union with the euro as a common currency in 1998 (Bergeijk et al. 2000) because we have genuine European heterogeneity and this implies that the benefits that countries reap from international trade differ substantially. This is an additional indication for the continued relevancy of economic diplomacy and commercial policy in an increasingly global economy.

\section{ECONOMIC DIPLOMACY AND NON-STATE ACTORS}

Building on the seminal definition of Baine and Woolcock (2003, p. 3) we can define economic diplomacy as a set of activities (both regarding methods and processes for international decision making) related to cross-border economic activities (export, import, investment, lending, aid, migration) pursued by state and non-state actors in the real world. Typically economic diplomacy at the state level consists of three elements.

- The use of political influence and relationships to promote and/or influence bilateral international trade and investment, to improve on functioning of markets and/or to address market failures and to reduce costs and risks of cross-border transactions (including property rights). Typically this subfield of economic diplomacy comprises commercial policy (export promotion, state visits and so on). We will often use the term 'bilateral economic diplomacy' to indicate this subfield. This will be the topic in Part II.

- The use of economic assets and relationships to increase the cost of conflict and to strengthen the mutual benefits of co-operation and politically stable relationships, that is to increase economic security. This subfield both contains structural policies and bilateral trade and investment agreements (aimed at achieving specific geographic trading patterns) and the political distortion of trade and investment as in the case of boycotts and embargoes. This will be the topic of Part III.

- Ways to consolidate the correct political climate and international political economic environment to facilitate and institute these objectives. This subfield is also indicated as 'trade diplomacy' 
(Woolcock 2002) and covers multilateral negotiations. It is the domain of the supranational organizations and institutions such as the World Trade Organization (WTO), the Organization for Economic Cooperation and Development (OECD) and the European Union (EU). We will not dwell too much on this subject in this book. One reason is that, generally speaking, the (potential) benefits of multilateral trade negotiations are well understood (see, for example, on the Uruguay Round: Hertel et al. 1999 and Brown et al. 2002 and on the Doha Round, Francois et al. 2003). Interestingly, studies also exist on the conflict reducing impact of international organisations such as the OECD (Wolfe 2003) and the success and failure factors of the diplomatic activities that are taking place within such organisations (for example, Heydon 2008 on the General Agreement on Trade in Services and the Multilateral Agreement and Investment). Also noteworthy is that the WTO (2007, pp. 35-111) provided an analysis of the political economy of trade co-operation on the occasion of the sixtieth anniversary of the multilateral trading system (that is the signing of the General Agreement on Tariffs and Trade in 1948).

The Baine and Woolwock definition rightly points towards the role of non-state actors and this offers two additional elements that need consideration in the analysis. This is especially so since the increasing role of non-state actors, such as multinational enterprises (MNEs), consumer groups and non-governmental organizations (NGOs) makes the international environment and the role and function of different types of 'diplomats' in firms and NGOs clearly different from the world in which we lived only a few decades ago (Saner and Yiu 2003).

\section{Producers}

Multinational enterprises are key players in the current phase of globalization. McCann and Acz (2008, pp. 13-14) sketch their impressive rise in the world economic system in the post-Second World War period.

At the end of the 1960s there were approximately only 7,000 MNEs in the global economy, and the ownership of these firms was accounted for almost entirely by just fifteen countries (... and) by 2006 an estimated 78,000 MNEs in the global economy with some 780,000 foreign affiliates (...). As such, the number of MNEs in the global economy has increased by more than eleven-fold in four decades, with the number of MNEs in the global economy increasing at a rate of approximately 1000-2000 per annum, while the number of MNE foreign affiliates has been increasing by $10,000-20,000$ per annum. 
It is not only the increase in numbers that matters, but also the sheer size of these MNEs. According to De Grauwe and Camerman (2002) about one third of the 100 largest economies in the world are corporations. According to their ranking of nation states and corporations (based on GDP and value added, respectively), ranks 1 to 43 inclusive are occupied by nation states, but Wal Mart, an American chain of large discount department stores ranks 44. The second largest corporation is Exxon with rank 48 just above New Zealand. Clearly these corporations are important decision making institutions and their activities and interests may form an important element of the global game. Such non-state actors can counteract the plans of national governments and since they have the option to shift activities between jurisdictions, governments have less grip on what these actors do and how they do it. Interestingly, such firms are also more vulnerable to pressures from large consumer groups that (can) boycott their products. Importantly, multinational firms that bow for consumer pressure and change their behaviour may thus become vehicles through which consumers exert influence on specific government, state or country activities.

\section{Consumers}

The strength of consumer boycotts has been well documented. The instruments of these boycotts comprise the refusal to buy goods and/or services (tourism, media) and divestment actions. In a number of cases, civil groups have exerted pressure (for example as shareholders) on corporations to actually implement the boycott. Indeed, as Herz (2001) remarks:

It would appear that people are exercising political choices not at the ballot box but by means of consumer activism. Corporations respond to consumer pressure in a way that governments do not, and are gradually assuming the role of global political actors.

Consumer boycotts have sought many goals that may even be multidimensional (see Grosso and Smith 2005). The first dimension concerns politics and human rights: the anti-Apartheid movement is a case in point. This was a transnational movement that included consumer boycotts of South African export products. The movement was especially effective in severing financial ties with the Apartheid government in the 1980s leading to an actual divestment from South Africa of some \$20 billion (Cortright and Lopez, 2002, pp 95-6.) The second dimension (a refusal to buy goods and services from firms that endanger the natural environment) is well illustrated by the case of the Brent Spar, an oil storage and tanker loading buoy, which Shell in 1995 wanted to dispose of in deep Atlantic waters. Greenpeace organized a worldwide, high-profile media campaign against this plan. Although 
Greenpeace never actually called for a boycott of Shell service stations, many customers turned to other firms. In the end Shell felt forced to dismantle the oil platform in an environmentally friendly way and recycle it. The third dimension, a relatively new one, is religion, for which the 2006 Danish cartoon crisis stands out as an example (Larsen 2006 and Andreasen 2008). Following the publication of a set of cartoons of the Prophet in a Danish newspaper in September 2005, a crisis emerged that also included violence against people, property and embassies. Many Muslims and supporters took part in protests throughout the world, but the big success was in international trade as one of the strongest consumer boycotts of all time emerged.

\section{Terrorism}

From the viewpoint of the Baine and Woolwock definition of economic diplomacy, a key distinguishing characteristic of modern terrorism à la $\mathrm{Al}$ Qaeda is that inter-country violence takes place at the non-state level (Bergeijk and Oldersma, 2006). Traditional terrorism often attacked foreign interests as well in order to put pressure on governments, but by and large such activities were limited to the geography of the nation state (or perhaps included some training facilities and bases in neighbouring countries). The 9/11 attack on US territory thus marked a new phase in transnational terrorism. It is often assumed that globalization facilitates transnational terrorism as the increasing volumes of travel, trade and finance would make detection of illegal activities much more difficult. Transnational terrorism increases uncertainty in general and reduces trust between and within trading nations and their populations. The challenge of transnational terrorism is that solutions should not be restricted to traditional state-to-state approaches but need to consider the involvement of non-state actors as well. The implications of these trend for economic diplomacy are not yet fully clear, but no doubt the decision making processes will become more complex since the number of players increases as does their heterogeneity. Also important is the fact that economic diplomacy will have to move beyond the old frontiers of government to government contacts. The new approach will have to address the needs and aspirations at decentralized levels, that is related to fuzzy groups of consumers and firms that are not represented by official bodies or governments because they live and work in a great many jurisdictions.

\section{ECONOMIC SECURITY}

It is tempting to investigate further how the use of economic assets and relationships can be used to increase the cost of conflict and trade disruption 
and also to investigate how the mutual benefits of co-operation can create politically stable relationships, that is to increase economic security. Indeed, interdependence and the mutual benefits that derive from international exchange are important economic incentives to reduce international political and military conflicts in the long run (Polachek, 1992).

Here the modern history of Europe is encouraging, both in pacifying the former belligerents France and Germany and in delivering democracy in formerly autocratically ruled countries such as Portugal and Greece (and later the countries in Eastern Europe). Indeed as Skylakakis (2006) remarks:

Economic diplomacy is also of great importance as a long-term instrument for conflict prevention. The most obvious example, and one of the greatest success stories of the past 60 years, is the creation and astounding success of the European Union.

The successful transformation from Marx to market and democracy in the former East Bloc does of course not only reflect the success of the European Union. The institutional setup for the western aid to the restructuring economies in Central and Eastern Europe in the early 1990s also played an important role: Article 1 of the Agreement establishing the European Bank for Reconstruction and Development (EBRD) limits eligibility for loans to those countries that are committed to and applying the principles of multiparty democracy, pluralism and market economies (Menkveld 1991). Theories and successes extend well beyond recent history and the European continent, as will become clear in the next chapter that reviews the literature.

The present chapter clarified the new challenges to economic diplomacy and economic security. Economic security as it is based on and/or building on international economic relations (such as trade in goods and services and capital flows, that is foreign direct investment, lending and development aid) will need consideration of the increasing complexity that is induced by globalization and decentralized decision making by an increasing number of actors in different jurisdictions. As will become clear, economic diplomacy has a viable role to play and may provide the risk management system for critical international situations. Successful and effective economic diplomacy will have to be based in both the public and the private sector in order to build economic security on a recipe in which stronger and broader bilateral economic relations provide the anchor of mutual interests and benefits.

\section{PLAN OF THE BOOK}

Part I (Chapters 2 and 3) will deal with the general aspects of trade uncertainty. Trade uncertainty is a central element in the analysis of economic 
diplomacy. Some instruments such as sanctions increase trade uncertainty while other instruments such as multilateral trade policy aim at reducing this uncertainty. Importantly, economic subjects may react differently towards a change in the level of trade uncertainty. In order to offer a better understanding Chapter 2 first reviews the history of economic thought on this subject and offers a detailed discussion of individual empirical studies that were summarized in the present chapter. Chapter 3 develops a general model to analyse trade uncertainty at the micro level of firms and consumers and at the macro level of the trading state thus offering an analysis of policy responses and bringing the political economy aspects into the picture. Against this background the next two parts develop specific elements of economic diplomacy: commercial policy and economic sanctions, respectively.

Part II deals with commercial policy and bilateral economic diplomacy. Chapter 4 deals with the economic rationale for public intervention in international activities, discussing the benefits from trade both in the context of macroeconomic analysis (economic growth) and in a microeconomic setting (that is firm-level data analysis). Next we will discuss the occurrence of border effects and investigate whether market failure might provide an explanation and see what instruments are available to solve the problems at hand without committing government failure. Particular attention is paid to recent empirical research on the international network of nation states, so as to provide a basis for comparison for Chapter 5 that investigates how trade and bilateral economic diplomacy interact. The chapter provides the results of an empirical investigation that relates trade performance of 36 countries in the year 2006 to export promotion agencies and embassies and consulates, thus extending the work of Lederman et al. (2006) and Rose (2007).

Part III analyses economic sanctions. Chapter 6 presents an empirical analysis of success and failure of 172 economic sanctions in the second half of the twentieth century. The findings offer empirical support for the theoretical approach developed in Chapter 3. Relevant findings include the structural break in the application and efficacy of economic sanctions that seems to have occurred around 1990 as well as the finding that the target's political system is an important determinant of success and failure of this instrument of economic diplomacy. Noting the lack of a comparable data set for positive instruments of economic diplomacy and building on these findings, Chapter 7 develops an expected utility model of rewards and threats (positive and negative sanctions) in an international context. One key finding regarding the tooling of economic diplomacy is that in the international system, negative sanctions and unconditional rewards are inferior to conditional rewards. The failure of unconditional exchanges focuses attention on the need to design mutually beneficial economic relations that emphasise conditionality, implying that exchanges should be reversible. 
Part IV develops a research agenda and draws policy conclusions. Chapter 8 offers some economic reflections on the 'market' for economic diplomacy. In the past the costs and benefits of diplomatic and economic relationships have not been expressed properly to decision makers, so that the actual outcome for diplomatic co-operation and diplomatic hostility has been inefficient. The aim of this book is to provide a better insight in order to reduce this inefficiency. The recent credit crisis, the climate issue and human rights issues have shown that globalization, although inevitable, cannot provide acceptable benefits unless progress is made in global governance of such issues. The efficiency of economic diplomacy is thus key to our future.

\section{NOTES}

1 See Felipe and Vernengo (2002) on the Methuen Treaty and the theory of comparative advantage and Duguid (2007) on the historical context of the Methuen Treaty and an overview of appreciations by contemporary observers.

2 Moreover, due to the treaty, Portugal did not further develop other agricultural products and its manufacturing industry. Consequently, it missed the industrial revolution. However, a clear political benefit was that the Treaty helped to preserve a power base regarding Portugal's most important colony, Brazil.

3 It may even have been worse. Sideri (1970) argues that the wrong type of specialization pattern was forced on Portugal.

4 See Neary (2004). The Geneva Round started in April 1947 with 23 countries and took 7 months. The Doha Round started in November 2001 with 141 countries and was 101 months underway when this book was finished in March 2009.

5 See, for example, Baldwin (2006), Leamer (2007) and McCann and Acz (2008).

6 Chang et al. (2004) review the literature and endogenize conflict, co-operation and trade with distance as one of the major drivers of political and economic interaction. For 30 countries in the years $1958-67$ they find that net conflict does not have a significant independent effect on trade but that trade enhances cooperation. See also Murshed et al. (2008) for an analysis in a bilateral context).

7 See, for example, Linders (2006). However, Brun et al. (2005) report a reduced impact of distance. A $10 \%$ larger distance was associated in 1962 with a $13.5 \%$ lower bilateral trade flow and a $12 \%$ lower bilateral trade flow in 1996 . The impact of distance on trade thus reduced by 1.5 percentage points (or $11 \%$ ). As this result occurred over a 35 year period, it is numerically disappointing from the point of view of those that believe in the death of distance hypothesis.

8 Other proposed explanations for the distance puzzle comprise Anderson and van Wincoop's (2004) 'distance neutral' technological progress or Frankel's (1997) suggestion that short-distance trade has benefited relatively strong.

$9 \quad$ Fratianni and Kang (2006b) recognized the existence of heterogeneity of distance elasticities across countries and country groupings; the point in this section is that the distance effects also change over time. 